\title{
6. Towards an uncertain community? The social effects of native title in central Cape York Peninsula
}

\author{
Benjamin R. Smith
}

\section{Introduction}

Aborigines in central Cape York Peninsula have lived alongside non-Indigenous pastoralists from the late-nineteenth century onwards. Despite a fraught and violent history, strong social ties developed between Aborigines and settlers during this period of coexistence. But in recent years these ties have become strained following a decline in Aboriginal employment on stations, the arrival of a number of new station owners and the passing of Queensland's Aboriginal Land Act 1991 and the Native Title Act 1993 (Cwlth). The success of the Wik and Wik Way People's native title claim - which determined that native title could coexist with pastoralists' rights on the central Peninsula's pastoral leases - has been particularly detrimental to social ties between Aboriginal people and settler pastoralists. ${ }^{1}$

In this paper I take up the theme of 'pathways out of the near-hegemonic relations of the past' (Redmond, Chapter 4), revisiting my earlier work on native title, certainty, and the coexistence of Aborigines and settler pastoralists in central Cape York Peninsula (Smith 2003). In considering such pathways, I also build on Patton's (1995) call for a more 'open' response to the possibilities offered by native title following the initial impetus of the Mabo No.2 decision and the NTA.

Writing shortly after the NTA's passage into law, Patton suggested that a more open response would be more likely to lead to progress towards social justice for Australia's Indigenous peoples. This progress would result from processual approaches to native title that would maximise rather than restrict:

options for Aboriginal communities ... to take a stand against forms of closure, in favour of openness or the continuous play of possibilities ... [this] amounts to demanding alegally and politically open-ended space of possibilities for action, a space of becoming that allows for the non-self-identical character of individual and collective agents (Patton 1995: 161-2).

\footnotetext{
1 In addition to settler pastoralists, a number of the region's Aboriginal people regard themselves as pastoralists. In recent years a number of these Aboriginal pastoralists have gained control of cattle properties, or have established their own herds on their homelands (see Smith 2000a, 2002, 2003).
} 
Such approaches would seek to enable 'openness' in relation to the outcomes of native title and the resulting possibilities for social justice and Indigenous futures. However, such openness can only hope to exist 'on the basis of specific mechanisms for identifying and dealing with native title' (Patton 1995: 162).

In this paper I seek to extend Patton's arguments through an anthropological consideration of the relation between 'openness' and social justice in the context of native title claims in central Cape York Peninsula. But rather than focusing only on the ways in which native title affects Indigenous Australians, I instead recast Patton's approach, conceptualising social justice in relation to a broader local or regional community affected by native title. As a 'total social fact' (Weiner 2003), native title affects not only Indigenous Australians but also the broader local communities associated with any given area for which native title is claimed or determined. Anthropological consideration of these communities, and the social fields (Gluckman 1949; Sullivan 2005) through which they are constituted, can shed light on the social effects of native title within a given locale. An anthropological engagement of this kind both points towards the ways in which some measure of social justice might be achieved within such fields, and indicates what forms social justice might take. A useful starting point for such an engagement is to consider the ways in which recognition and coexistence already take place within a particular social field and may thus be extended from existing foundations.

\section{The limits of recognition}

The most concerted discussion of recognition in the context of native title stems from Noel Pearson's (1997) model of the recognition space, which presents legal recognition as being constituted in an overlap between distinct fields of Aboriginal law and Australian law. ${ }^{2}$ Martin (2004: 68) rightly emphasises the particular character of the process of recognition represented by this model, arguing that it involves a fundamentally transformative mode of translation that is brought to bear on those aspects of Aboriginal law that are 'recognised'. This forceful translation is made possible by the dominance of the categories of Australian property law within the recognition space. But Martin also notes that the native title recognition space is 'only one dimension of the complex zone of social, cultural, political and economic interaction between Indigenous and non-Indigenous societies' (Martin 2004: 68).

Patton is similarly critical of the operation of recognition enabled by the Native Title Act, describing it as 'a secondary reterritorialisation [of "recognised" customary law] by legislative means' (Patton 2000: 126). The term

2 Although Pearson has more recently resiled from this conceptualisation of native title (see Martin 2003: 2-3), the recognition space model has remained influential, not least in anthropological discussions of native title. Among those who have drawn on Pearson's model are Mantziaris and Martin (2000), Martin (2003, 2004), Sullivan (2001), and Weiner (n.d.). 
'reterritorialisation' used by Patton suggests both that customary law is taken over or 'captured' by Australian law, and also that it becomes a mere object of the categories of the NTA and of Western legislative practice more generally. ${ }^{3}$ But despite this, Patton is more equivocal than Martin in his account of the forms of translation that occur in the process of recognition:

the recognition of native title involves a becoming-indigenous of the common law to the extent that it now protects a property right derived from indigenous law; and a becoming-common law of indigenous law to the extent that it now acquires the authority along with the jurisprudential limits of the common law doctrine of native title (Patton 2000: 129).

Like Martin, Patton's analysis is suggestive of the kinds of translation that occur in any act of recognition. ${ }^{4}$ In the native title process, recognition means that the character of Aboriginal law is at least partly transformed as a result of its acquiring the jurisprudential limits of the common law's articulation of native title. But Patton also suggests that the process of transformation operates in both directions. The common law 'becomes indigenous' in its extension of protection, through recognition, to proprietary interests previously articulated only within the domain of Aboriginal law. On this basis, Patton suggests that the recognition of native title also involves 'a partial deterritorialisation of the legal apparatus of capture by means of refusal of its primary stage: the establishment of a uniform space of comparison and appropriation' (Patton 2000: 129). Rather than mere capture and objectification, then, the native title process might allow Aboriginal law to exert a transformative effect on the Australian legal apparatus. By maintaining substantial aspects of Aboriginal law in the space of 'mainstream' legal practice, this would radically undermine the uniform space of Australian law, 'opening' it through the introduction of cultural difference within that space. $^{5}$

Of course, Patton was writing at a time in which the radical potential of native title seemed greater than has actually proved to be the case. The 1998 amendments to the NTA and the developing trajectory of native title case law have served to limit any deterritorialisation of Australian law. In retrospect it seems that Patton was being overly optimistic in his suggestion that Aboriginal law and custom would be able to avoid capture within a uniform space of comparison and appropriation in native title claims. Rather, history has supported Merlan's (1998: 175) suggestion that the NTA would assimilate customary rights

\footnotetext{
3 Patton draws the terms 'reterritorialisation', 'deterritorialisation' and 'capture' from the work of Giles Deleuze, and in particular from Deleuze and Guattari (1987).

4 On the problems of translation in the context of native title see also Morphy (Chapter 2); Glaskin (Chapter 3) and Lahn (Chapter 7).

5 See Morphy (Chapter 2) for an example of the introduction of Aboriginal law within the native title process despite the best efforts of the court to maintain the uniform space of Australian law.
} 
and interests into 'the existing class of property rights at common law' only so far as such rights and interests can be dealt with by Australia's legal system. ${ }^{6}$ The formal outcomes of native title claims have increasingly tended towards the radical translation of limited aspects of Aboriginal Law within the recognition space. Nonetheless, the wider social fields within which native title is enacted may yet bear out Patton's hope for the development of heterogeneous spaces of interaction between Aboriginal and non-indigenous life-worlds. What is lost in the formal aspects of determination may persist in other aspects of the complex zone of interaction between Aborigines and settlers. But rather than existing as a result of forms of 'social, cultural, political and economic interaction between Indigenous and non-Indigenous societies' (Martin 2004: 68, emphasis added), in central Cape York Peninsula such heterogeneity seems to be situated within shared social fields.

Indeed, despite its formal, legalistic emphasis, native title may yet prove to have contributed to meaningful coexistence by further intensifying social relationships between Aborigines and settlers in places like the central Peninsula.

\section{Fundamental coexistence}

Previous accounts of native title have tended to conceive of recognition as occurring in an overlap between different bodies of law, or as an interaction between substantially distinct Aboriginal and settler societies. Such accounts tend to conceive of native title relatively narrowly, in terms of a legal process focused on the articulation of systems rather than as an event taking place within the daily lives of claimants, respondents and other interested parties.

If we place native title within its broader social context, we are able to include within our analyses not only the formal aspects of recognition-those driven by the operation of the Native Title Act-but also other kinds of recognition. These other kinds of recognition occur elsewhere in the complex zone of interactions between Aborigines and settler Australians. Within this zone, the analysis of native title (and in particular its social effects) becomes centred on questions concerning coexistence. Indeed, viewed from within this zone, coexistence is revealed as existing prior to a native title claim, and as the foundation upon which any act of recognition, formal or otherwise, is able to occur.

This prior coexistence takes various forms. At its most diffuse it exists at the level of the Australian nation-state, which provides both the limit and the necessary social and legal framework for native title per se. But the coexistence that underpins native title as a total social fact also occurs in more limited and

6 Merlan (1998: 176) also notes that, at the time of writing, other interpretations of native title were emerging 'that would allow some freedom from constraining ... structures'. 
socially substantial forms. Perhaps most importantly, this prior coexistence occurs in the form of the local social field or community that is concerned with a particular area subject to a native title claim.

In using the term 'community', I am mindful of the problems of its suggestion of a homogenous character or substantial identity to those Aboriginal people who live together in a particular locality. ${ }^{7}$ Regarding the social effects of native title, however, it is useful to consider community in the sense identified by Wagner (1967: 186, 207-17, 1988: 44-45, 59). For Wagner, communities are not pre-existing social entities sharing a single identity. Rather, communities are continually emergent in the social interactions between those living alongside and interacting with one another. The 'concretivity' of such communities 'is that of locale and event rather than continuative substance or identity'. For this reason 'they are not so much the objects as the subjects' of ongoing local histories (Wagner 1988: 59).

In central Cape York Peninsula-and particularly in Coen, the region's main township - this usefulness of this notion of community is not limited to those Aboriginal people who live together in the town and in 'outstation' camps in the township's hinterland. Community of this kind also inheres amongst the wider regional population, both Aborigines and settlers, whose interactions continue to lie at the heart of regional sociality. In this region-as elsewhere in Northern Australia - the communities whose coexistence is the basis of the social effects of native title include many, if not all, of those Aborigines and 'whitefellas' who live within or close to the area subject to a native title claim. ${ }^{8}$

The work of the French philosopher Jean-Luc Nancy (e.g. 1997, 2000) clarifies the importance of the prior coexistence of such communities in relation to the social effects of native title. For Nancy, coexistence is the fundamental 'groundform' of all human life-worlds. What consociates have in common is not merely more or less specific ways of thinking, being and acting, possessions or property rights and the like which tie together a series of individuals. Coexistence - 'being-with' others - is not merely a secondary aspect of human existence; rather, coexistence is the fundamental condition of existence in general. It names the way in which we can only meaningfully exist through our ongoing relations with others; the character of our existence depends on the community that we share with our consociates. This shared situation provides "the capacity in and by which something, "some-things"" and "some-ones" come to "be"

\footnotetext{
7 See Peters-Little (2001) and Sullivan (1996) for critical accounts of the use of the term 'community' in relation to Aboriginal Australians.

8 The arguments regarding coexistence made here might also be usefully expanded to include others who, despite not living locally, understand themselves as having an interest in a given area, and act in relation to that interest. This might include, for example, State or Federal agencies concerned with a particular tract of land, and members of the 'stolen generations' or Aboriginal 'diaspora' (Rigsby 1995; Smith 2000b), who are typically also involved in native title processes.
} 
(Nancy and Ten Kate 2004). Within community the enactment of recognition, on the basis of coexistence, thus generates both particular social effects (e.g. 'rights and interests' and their 'enjoyment') as well as one's sense of selfhood, the latter being at least partly constituted in relation to the former. As such, coexistence might be understood as the 'groundform' of recognition where native title is understood as a total social fact.

Another name for this fundamental form of coexistence is 'the inter-' (Nancy and Ten Kate 2004). Given that Northern Australian life-worlds are now self-evidently constituted through 'the co-presence of people with different ideas and forms of action' (Merlan 2005: 169), ${ }^{9}$ it is perhaps not surprising that anthropologists working in that region-as well as philosophers like Nancy - have placed the 'inter-' at the heart of their analyses. Merlan (2005: 169), for example, has drawn on various theories of intersubjectivity, which 'do not begin with a notion of a pre-existing "subject" ... [but rather] from a notion of interrelationship and its specific moments of interaction' to model the character of coexistence in the Katherine region of Australia's Northern Territory. For Merlan, these accounts of intersubjectivity can usefully be the basis of understanding the 'intercultural' situations that now predominate across much of Northern Australia:

In a similar fashion [to the way in which the 'inter-' operates in theories of intersubjectivity], I was looking for a formulation of the 'cultural' which recognizes difference but does not begin from an overspecified notion of 'culture'; as well as for a way of writing about relations 'between' people that focuses on the processual character of interrelationship ... An 'intercultural' description needed to emphasize processes of reproduction as well as non-reproduction of socio-cultural patterns, interaction, and the varieties of reflexivity of participating subjects (Merlan 2005: 169).

Even where social life depends on sharply demarcated social boundaries - between Aborigines and whites in most North Australian towns for instance - one can nonetheless perceive such a substantive interrelationship 'of categories, understandings, modes of practical action' (Merlan 2005: 170). Moreover, rather than being pre-given, the character of such interrelationships necessarily means that Aboriginal categories, understandings and modes of action are reproduced and reshaped in interaction, interrelationship and

\footnotetext{
9 This has, of course, always been the case; in small scale 'societies' like those extant in Australia at the 'threshold of colonization' (Keen 2004), the power of various understandings and actions to reshape both the social field and local cultural production is pronounced. However, only when anthropologists have been both methodologically and practically confronted with the co-presence of radically different ways of thinking and acting has the anthropology of Northern Australia begun to properly grapple with the question of the 'inter-'. (See the essays in Hinkson and Smith 2005 for a series of contributions on this theme).
} 
event - sometimes in engagement with whites' (Merlan 2005: 170). ${ }^{10}$ Here Merlan's account of the 'inter-' points towards the iterative character of all meanings, norms, and practices, which are continually reshaped in interactions between Aborigines and settlers as well as in interactions among Aborigines.

In Coen, for example, the interactions between Aborigines and local whites have been transformative of the life-world of the wider Coen community, despite ongoing social distinctions between Aborigines and whitefellas. Such transformations were particularly marked during the period of majority employment of Aboriginal people on the region's cattle stations. On these stations the formal distinctions between Aborigines and whites were often weakened, resulting in intense forms of consociality between them (see also Redmond 2005). The day-to-day patterns of station consociality and the mutual exposure of Aborigines and whites to each others' ways of dealing with the region's landscape resulted in the reshaping of whites' and Aborigines' forms of knowledge and practice relating to the landscape and to each other (Smith 2002, 2003). But a decline of Aboriginal employment on stations from the late 1960s and early 1970s onwards has since increased the sense of social distance between most Aborigines and settlers until recently, when the establishment of a local Aboriginal Corporation in Coen and advent of land claims and native title have led to more substantial interactions between Aboriginal people and the settler population in the central Peninsula (Smith 2000a).

On first glance, Merlan's 'inter-' is of a somewhat different order to Nancy's, dealing with particular instances of social and cultural life, rather than coexistence as a more abstract groundform of sociality. Nancy, however, argues that this 'groundform' only ever exists within the various enactments of social life. As such, Nancy's 'inter-', like Merlan's, inheres in the ongoing social articulation of categories, understandings and modes of practical action. If the 'inter-' is a groundform, it does not sit outside of everyday sociality; rather, it is that sociality, coexistence or community in each of its ongoing manifestations. The 'inter-' exists only in the interactions of consociates that ensure that there is a continually 'open' character to local life-worlds, even as they draw upon and reiterate established socio-cultural forms. This open character means that the possibility of change and creativity - Patton's 'deterritorialisation' - inheres continually in social life, providing it with its vitality.

Placing the 'inter-' at the heart of the socio-cultural field thus reveals all cultural production $^{11}$ as inherently intercultural. Whilst every social interaction depends on previously established meanings and norms, these are simultaneously

\footnotetext{
10 Needless to say, the categories, understandings and modes of action of whites are also subject to transformations through interactions with Aborigines. However, the effects of local power relations, racism, and wider structural factors may mitigate the transformations produced through such interactions. 11 Here I follow Merlan's $(1998,2005)$ use of the term to indicate the continuing iteration of particular cultural categories, understandings and modes of practical action within day-to-day social life.
} 
reshaped - either subtly or radically - in the course of all interactions. This is not to say, of course, that meanings and norms are not maintained over time, nor that cultural differences and incommensurability are not more evident in some interactions than in others. Von Sturmer's (1984) discussion of the 'Aboriginal domain', for instance, makes it clear that distinctly Aboriginal styles of thought and action have persisted across Northern Australia despite the encapsulation and saturation of Aboriginal populations by 'mainstream' Australian society. The domains in which these styles of thought and action persist are maintained through intense, ongoing interactions among Aborigines at a remove from non-Indigenous consociates and local manifestations of the 'mainstream'. Further, even where long-term interactions between whites and Aborigines have taken place for generations, it is not uncommon for incommensurable understandings and actions to predominate. Despite a lifelong history of co-residence by Aborigines and whites in Coen, it is not uncommon for misinterpretation and incommensurability, rather than shared meanings and norms, to predominate in their interactions.

The ongoing misunderstandings and incommensurability between whites and Aborigines suggests that whilst the coexistence of local communities depends on particular perceptions or understandings about consociates - that is, on forms of recognition - such recognition is not necessarily either accurate or affirmative in character. Coexistence in central Cape York Peninsula has long involved 'recognition' in the form of racist stereotypes of local Aboriginal people. Local whites have variously seen Aborigines as savages, backwards, primitive, in need of supervision and guidance, as not owning land and as an available source of indentured labour for the region's cattle stations. At the same time, despite the continuing existence of such stereotypes, recognition has also taken more positive forms, for example in the ongoing close social bonds that have developed between local Aborigines and white pastoralists. ${ }^{12}$ Even as coexistence depends on recognition, recognition - whether affirmative or negative in character - always falls short of the underlying 'openness' of coexistence. If the recognition enacted in the formal determination of native title is particularly ossifying and transformative of Aboriginal identities (Smith 2003; see also Glaskin, Chapter $3)$, its actions are nonetheless illustrative of the effects of recognition more generally.

Any act of recognition, legalistic or otherwise, reduces the potential of coexistence through an unavoidably reductive, particularistic framing of relationships and identities. Such acts are always regulative, in the sense that they bring a necessary definition to social interactions. Whilst they serve to

\footnotetext{
12 Redmond (2005) usefully writes of these close social bonds, and the forms of misunderstanding and incommensurability that persist within and partly constitute them, in terms of R. D. Laing's notion of the 'family phantasy'.
} 
enable sociality, they simultaneously limit it by foreclosing (at least temporarily) other potential forms of interaction. In identifying someone as a 'claimant', for example, all other possible relationships with that person are (temporarily, at least) subsumed by an interaction on the basis of that identity.

Given that the formal recognition offered by native title may be necessary to restore some wider meaning to Aboriginal customary interests, it is important to recognise that the ossifying effects of such recognition may be mitigated in other areas. The principal possibility for such mitigation inheres in the enactment of 'rights and interests' within the social life of local communities. If the formal recognition enacted within the 'recognition space' is necessarily dominated by a Western legal demand for certainty, based on a legalistic 'ontology of determinacy' (Smith 2003: 41, after Gaonkar 2002: 6), a more open style of recognition may nonetheless be maintained elsewhere in ongoing social interactions between Aborigines, local non-indigenes and others concerned with a particular area. This open style of recognition would not be overdetermined by fixed legal categories, but would rather subsume these categories within the complex field of ongoing social relations.

In this way the 'openness' required to achieve some measure of social justice for Aborigines may still be found in the context of native title, but only where the ongoing negotiation of the meaning of 'rights and interests' can take place in the interactions between native title holders and their consociates. This negotiation must therefore take place in the context of the wider community concerned with a particular area where native title has or will be determined, allowing for the establishment of relatively satisfactory coexistence between its members.

Social justice will thus never be brought about simply by a determination of native title. Instead, native title law can only impel an adjustment in the forms taken by local coexistence, which - in order to be both meaningful and relatively satisfactory for all members of a local community - must always exceed the 'letter of the law'. Legal processes, in and of themselves, will always be unsuccessful in their attempts to produce social justice. The 'thin simplifications' (Scott 1998) that such determinations represent can only ever be meaningful in the context of ongoing social interactions, although they may exert powerful leverage within these interactions. Here law and justice are both distinct yet inseparable; justice itself may remain incalculable, but any aspiration towards justice nonetheless requires an act of calculation, in particular through the application of law (Derrida 2002: 257). If the enactment of the law aspires to the achievement of just outcomes, social justice - situated in the 'open' exposure of consociates to one another - is nonetheless never simply achieved or arrived at. Social justice inheres in a sufficient potential for relatively satisfactory coexistence 
between members of a given community, not in the ossified articulation of rights and interests.

\section{Beyond formalism, towards community?}

One of the most important aspects of Martin's critique of the native title 'recognition space' is that the form of recognition that constitutes that space is dominated by the categories of Australian property law (see also Patton 1995: 158). Although this space is intercultural in a specific sense, marking the articulation of Aboriginal law and 'mainstream' Australian law, the forms of practice through which it is constituted are overwhelmingly based on the norms and interests of non-Indigenous parties. Further, given the fraught histories of relationships between Aborigines and white pastoralists in areas like central Cape York Peninsula, there is a considerable danger of reproducing the culturally biased character of the formal recognition space in the other forms of recognition through which native title is realised as a total social fact.

If Patton's hope for the possibility of more open outcomes from native title claims is to be realised within the complex zone of interactions between Aborigines and settlers, then more open forms of coexistence will need to be realised in day-to-day interactions between settlers and Aborigines than are provided for in native title determinations. Further, these forms of coexistence will necessarily have to be more inclusive of specifically Aboriginal forms of knowledge and practice in order to avoid the cultural hegemony that marks native title's formal recognition.

In the central Peninsula, consent determinations of native title between Aboriginal claimants and station owners typically depend on the negotiation of Indigenous Land Use Agreements (ILUAs). These negotiations are often been bogged down by discussions over formal sets of rules regarding Aboriginal land use. Nonetheless, despite an often stated dislike of 'lawyers and paperwork', settler pastoralists, as well as their legal representatives, are typically convinced of the ability of such formal arrangements to deliver them the 'certainty' that they require in order to consent to a native title determination. The need for such rules is typically argued for as providing 'certainty' for the continued running of a cattle business. For instance, pastoralists have argued that they require temporary exclusion zones on their properties during the mustering of cattle, or that they require explicit agreement that gates will be shut after they have been used. But pastoralists also seek 'certainty' regarding their lifestyles, for instance in seeking formal agreement about privacy zones covering a large area surrounding a homestead. ${ }^{13}$

13 In ILUA negotiations, pastoralists in the central Peninsula have also sought certainty about who and what they are dealing with in the context of native title, requesting lists of those Aboriginal people who claim traditional connection with their properties, so they know exactly whose enjoyment of native title rights they have consented to, as well as maps of 'sacred sites' to be avoided during station work. 
Arguments of this kind have often threatened the considerable goodwill of Aboriginal claimants, who see no need for formal delineation of such matters. Rules intended to ensure the proper running of cattle stations have proved particularly irksome. As one man put it, allowing himself an unusual display of public irritation, 'we've been working on stations all our life ... we know what to do and what not to do'. Such irritation is not simply due to a denial of Aboriginal knowledge about how a station operates; it is also a reaction to an implicit denial of shared working and life histories between white station owners and Aborigines. ${ }^{14}$

Although seemingly irritated by the need for formal agreements regarding their use of their country within pastoral leases, Aboriginal claimants tend to be more sympathetic to pastoralists' concerns about privacy. In the negotiations I have observed or taken part in, such concerns are typically met with assurances that the right of the pastoralists to enjoy their privacy is accepted by the claimants, as is their need to be able to run their stations properly. This sympathetic reaction demonstrates a widespread acceptance by Aboriginal people across Northern Australia's pastoral regions of settlers' own rights in relation to stations they have established often over several generations (Redmond 2005: 242; Smith 2003: 37). Similar rights also seem to be extended to those pastoralists who have bought and taken up their station properties more recently. ${ }^{15}$

The kinds of formal arrangement discussed during the negotiation of ILUAs appear to be far from satisfactory, despite Aboriginal sympathy for some of the outcomes sought by pastoralists. In the central Peninsula, such arrangements are likely to lead to one of two results. Firstly, the literacy requirements for the use of formal agreements will, in most cases, lead to their being ignored or their contents guessed at or remembered by native title holders. Secondly, the legal formality of such agreements, combined with the adversarial character of the negotiations leading to a consent determination, may well dissuade native title holders from seeking to enjoy their 'rights and interests', even where these are found to be legally coexistent with those of station owners.

Enjoyment of native title rights on cattle properties is instead more likely to occur where such formal arrangements have been put to one side, and where Aborigines have been encouraged by station owners to 'ring up and drop in for a cup of tea and a yarn' on their way to fishing on a creek or river within the

\footnotetext{
14 In one ILUA negotiation, pastoralists attempted to mitigate the offence caused by their assertions for formal rules for native title holders' conduct on stations by displacing the reason such rules were needed onto 'younger [Aboriginal] people ... who might come onto the place and leave beer cans everywhere, leave gates open or not put out [camp] fires'. But this attempted displacement only caused further offence.

15 Such sympathy also seems to draw on a common norm in Aboriginal Australia that even on someone else's country, the space of a person's camp is their own, and should not be trespassed upon by even senior men and women upon whose country the camp is located.
} 
station boundaries. This outcome is more likely when friendly relations have been established, regenerated or reiterated between pastoralists and claimants in the course of native title negotiations.

For Aboriginal claimants in the central Peninsula, the power of this kind of invitation to shape future outcomes from a native title claim extends beyond general social niceties. Within local Aboriginal life-worlds, an insistence on not 'just going past' someone, but stopping to 'yarn' and share food and drink, is a clear statement of social connectedness. Not to do so is to mark one's relationship (or lack thereof) as one between 'strangers' or 'stranger people'. ${ }^{16}$

Likewise, negotiations that open out towards a more general, informal sociality resonate with local Aboriginal social norms, whilst negotiations that lead only towards the recognition of formalised rights and interests held in opposition to those of station owners do not. In the central Peninsula's 'Aboriginal domain', the normative expectation is of the maintenance of informal, friendly sociality among consociates. Despite the fact that the Aboriginal domain contains a series of potential forms of recognition constitutive of social differentiation or personal autonomy, the general tendency is one of social inclusion and an emphasis on relatedness rather than social distinction. ${ }^{17}$ Unlike those accustomed to the cultural norms that inhere in nation-states, Aboriginal people remain predisposed not to understand - let alone enact - 'rights and interests' outside the context of lived social relationships. ${ }^{18}$ As such, the idea that one might simply enjoy 'rights and interests' on the basis of 'paperwork' is at best puzzling, and at worst practically impossible.

In order to lead to the realization of meaningful property rights, native title in places like the central Peninsula must involve ongoing informal mutual recognition between local Aborigines and pastoralists on an 'open' basis. This kind of recognition, where it takes place, has restored meaningful forms of local community in which it is not only formalised rights and interests, but the ways in which such rights and interests become locally meaningful that come to constitute coexistence.

'Open' coexistence of this kind also tends to be restorative of meaningful forms of community (something that both Aborigines and settler pastoralists have claimed that they would like to see happen following ILUA negotiations). Rather than a homogenous community defined by a shared identity or lack of

\footnotetext{
16 Importantly, the sharing of food — or the provision of separate food for Aborigines and whites — during past station employment is seen as marking the character of employment by white 'bosses' for many of the region's Aboriginal people.

${ }^{17}$ On the interplay of autonomy and relatedness in the Aboriginal domain, see Martin (1993) and Myers (1986).

18 A key means by which social relatedness is affirmed is in the sharing of resources, including acquiescence to requests for access to land and waters. Importantly for the purposes of the present argument, such requests are only made where a warm and positive response is anticipated.
} 
differentiated interests, or an array of formally differentiated social and legal persons, this community is instead constituted through the fundamental coexistence of its members' sharing of locale and event as the subjects of ongoing local histories (Wagner 1988: 59). As such, it is a community that is fundamentally uncertain, this uncertainty being a reflex of the 'openness' through which it continues to be enacted.

The possibility for this kind of 'openness' now seems to be excluded within the increasingly 'juridified' domain of the Native Title Act, ${ }^{19}$ which increasingly delivers judgements of ownership that are 'uncontestable, certain, concrete [and] decontextual - in short, monumentalising abstractions' and which are 'far from the multivalent determinations of custodianship that once marked indigenous ritual-political life' (Austin-Broos 2004: 213, citing Povinelli 2002: 227). As I have argued above, even given the forms of abstraction that now predominate within the formal 'recognition space', this kind of uncertain community can nonetheless still exist between Aborigines and settlers in their day-to-day recognition of each other's involvement with country. But despite Northern Australian pastoralists' general dislike of formality, state bureaucracy and legal processes (cf. Kapferer and Morris 2003), subscription to the Australian notion of a 'fair go', and commonly stated desire to return to what are seen as previous 'good relations' with local Aborigines, it has taken the force of Australian law and a more general societal shift towards the recognition of Aboriginal 'rights' to impel local whites towards this more equitable form of local recognition.

\section{Conclusion}

In contradistinction to the certainties aspired to in codifying a 'community of native title holders' and their 'rights and interests', it remains possible for whitefellas and Aborigines in central Cape York Peninsula to coexist as members of an uncertain community. This community is constituted through a more 'open' and processual style of recognition than that provided for in formal determinations of the coexistence of native title and pastoral leases. Given that this style of recognition - where it occurs - is reminiscent of the forms of sociality that characterise the 'Aboriginal domain', it seems to represent a move towards a culturally heterogenous space of interaction, rather than one dominated either by the legal and social norms of 'mainstream' Australian society, or earlier local forms of white hegemony.

Aborigines in the central Peninsula have long understood such coexistence to exist, despite the long history of their domination by white 'bosses' on the region's cattle stations. But a meaningful engagement with this kind of coexistence by pastoralists has depended on the force of Australian law and a

19 Here I follow Martin and Mantziaris (2000) in referring to the increasing juridification of native title. 
growing realisation that, in the longer term, any future certainty depends on their accommodation of the aspirations of their Aboriginal neighbours.

With this in mind, comments made by pastoralists and their solicitors during a court hearing for a consent determination of a native title claim in the central Peninsula are particularly interesting. In their comments, the pastoralists emphasised the importance of interpersonal relationships between pastoralists and the Aboriginal claimants both in reaching the consent determination, and in translating this determination of native title back into meaningful day-to-day relationships:

MR K_[solicitor and co-owner of S_station]: Thank you, your Honour. The pastoralists that I represent consent to the determinations of Native Title. Your Worship, the Court cannot make any order, nor can any government legislate, in respect of how the parties, the pastoralists and the Native Title holders can co-exist and work together to build relationships for the future. This has been achieved by agreement, and it is a tribute to the foresight and open mindedness displayed by the parties and is an example to others as to how outcomes might be achieved by negotiation. Thank you, your Honour.

HIS HONOUR: Thank you. Mr F_?

MR F_ [co-owner of S_ station]: May it please the Court, the lessees of S_ [station] consent to determination. I also would like to pay tribute to the traditional owners of this place and, in particular, the $\mathrm{W}_{-}$People. I would also like to mention, especially, the traditional owners for [ $\mathrm{S}_{-}$ station]. It might interest the Court to know that approximately five years ago we decided we weren't progressing fast enough, I guess is the terminology, and insisted, for the first time, that we meet the traditional owners face-to-face. And I think from that point on we made a lot of progress, and I think it is fair to say today that, with the lessees of $\mathrm{S}_{-}$ and myself, that those relationships in some cases have developed into friendships. So it looks very good for the future.

And I do have to say that, ... that when you sort of look around and have a look at all the time we've been working on this and realise that this is what we wind up at the end of it, the people sitting in the gallery could really be forgiven for wondering what the blazes we' ve been doing.

So what had the various parties been doing all this time? A number of things, but not least bringing about a situation in which the pastoralists and their legal representatives, as well as other parties, were prepared to recognise the 'traditional owners' as such.

The fraught process by which consent determination was reached in this claim indicates the interminable interrelation between law and justice. In central Cape 
York Peninsula, where there has been a long history of injustice, the forms of recognition offered by the Native Title process, flawed though they may be, have nonetheless provided a means to return station owners to a more open and just dealing with local Aborigines.

While the native title process can produce its own injustices through the particular style of formal recognition on which it depends, it can also act to re-open a space for more just forms of coexistence. This uncertain space of interaction between Aboriginal people and settler pastoralists is marked by a 'face-to-face' style of recognition and interaction which continues to build relationships into the future, It seems that in allowing for a more open, processual style of interaction, even as it excludes openness from its formal operation, the native title process may potentially lead to the social justice hoped for by Patton, despite the limited results often offered by determination itself.

\section{References}

Austin-Broos, D. 2004. 'Anthropology and Indigenous alterity: book review essay (E. Povinelli, 2002. The Cunning of Recognition: Indigenous Alterity and the Making of Australian Multiculturalism)', The Australian Journal of Anthropology, 15 (2): 213-16.

Deleuze, G. and Guattari, F. 1987. A Thousand Plateaus: Capitalism and Schizophrenia, University Of Minnesota Press, Minneapolis.

Derrida, J. 2002. 'Force of law: the "mystical foundation of authority"', in J. Derrida, Acts of Religion (ed. G. Anidjar), Routledge, London.

Gaonkar, D. P. 2002. 'Towards new imaginaries: an introduction', Public Culture, $14(1): 1-19$.

Gluckman, M. 1949. An Analysis of the Sociological Theories of Bronislaw Malinowski, Rhodes Livingston Institute Papers 16, Oxford University Press, Cape Town.

Hinkson, M. and Smith, B. R. (eds), 2005. Figuring the Intercultural in Aboriginal Australia, Special Issue, Oceania, 75 (3).

Kapferer, B. and Morris, B. 2003. 'The Australian society of the state: egalitarian ideologies and new directions in exclusionary practice', Social Analysis, 47 (3): 80-107.

Keen, I. 2004. Aboriginal Economy and Society: Australia at the Threshold of Colonisation, Oxford University Press, Melbourne.

Mantziaris, C. and Martin, D. F. 2000. Native Title Corporations: A Legal and Anthropological Analysis, Federation Press, Sydney. 
Martin, D. F. 1993. Autonomy and Relatedness: An Ethnography of the Wik People of Western Cape York Peninsula, PhD Thesis, The Australian National University, Canberra.

Martin, D. F. 2003. 'Rethinking the design of indigenous organisations: the need for strategic engagement', CAEPR Discussion Paper No. 248, Centre for Aboriginal Economic Policy Research, The Australian National University, Canberra.

Martin, D. F. 2004. 'Designing institutions in the 'recognition space' of native title', in S. Toussaint (ed.), Crossing Boundaries: Cultural, Legal, Historical and Practice Issues in Native Title, Melbourne University Press, Melbourne.

Merlan, F. 1998. Caging the Rainbow: Places, Politics, and Aborigines in a North Australian Town, University of Hawai'i Press, Honolulu.

Merlan, F. 2005. 'Explorations towards intercultural accounts of socio-cultural reproduction and change', in M. Hinkson and B. R. Smith (eds), Figuring the Intercultural in Aboriginal Australia, Special Issue, Oceania, 75 (3): 167-82.

Myers, F. 1986. Pintupi Country, Pintupi Self: Sentiment, Place, and Politics Among Western Desert Aborigines, University of California Press, Berkeley.

Nancy, J.-L. 1997. The Sense of the World (translated by J. Librett), University of Minnesota Press, Minneapolis.

Nancy, J.-L. 2000. Being Singular Plural (translated by R. Richardson and A. O'Byrne), Stanford University Press, Stanford.

Nancy, J.-L. and Ten Kate, L. 2004. “"Cum”...revisited: preliminaries to thinking the interval', in E. Ziarek and H. Oosterling (eds), Intermedialities, Continuum, New York.

Patton, P. 1995. 'Post-structuralism and the Mabo debate: difference, society and justice', in M. Wilson and A. Yeatman (eds), Justice and Identity: Antipodean Practices, Allen \& Unwin, Sydney.

Patton, P. 2000. Deleuze and the Political, Routledge, London.

Pearson, N. 1997. 'The concept of native title at common law', in G. Yunupingu (ed.), Our Land is Our Life, University of Queensland Press, St Lucia.

Peters-Little, F. 2001. 'The community game: Aboriginal self definition at the local level', in F. Morphy and W. Sanders (eds), The Indigenous Welfare Economy and the CDEP Scheme, CAEPR Research Monograph No. 20, Centre for Aboriginal Economic Policy Research, The Australian National University, Canberra. 
Povinelli, E. 2002. The Cunning of Recognition: Indigenous Alterity and the Making of Australian Multiculturalism, Duke University Press, Durham.

Redmond, A. 2005. 'Strange relatives: mutualities and dependencies between Aborigines and pastoralists in the Northern Kimberley', in M. Hinkson and B. R. Smith (eds), Figuring the Intercultural in Aboriginal Australia, Special Issue, Oceania, 75 (3): 234-46.

Rigsby, B. 1995. 'Tribes, diaspora people and the vitality of law and custom: some comments', in J. Fingleton and J. Finlayson (eds), Anthropology in the Native Title Era: Proceedings of a Workshop, Australian Institute of Aboriginal and Torres Strait Islander Studies, Canberra.

Scott, J. C. 1998. Seeing Like a State: How Certain Schemes to Improve the Human Condition Have Failed, Yale University Press, New Haven.

Smith, B. R. 2000a. Between Places: Aboriginal Decentralisation, Mobility and Territoriality in the Region of Coen, Cape York Peninsula (Australia), PhD Thesis, Department of Anthropology, London School of Economics and Political Science, London.

Smith, B. R. 2000b. 'Local and diaspora connections to country and kin in Central Cape York Peninsula', Native Title Research Unit Issues Paper Vol.2, No.6, Native Title Research Unit, Australian Institute of Aboriginal and Torres Strait Islander Studies, Canberra.

Smith, B. R. 2002. 'Pastoralism, land and Aboriginal existence in central Cape York Peninsula', Anthropology in Action, 9 (1): 21-30.

Smith, B. R. 2003. 'Whither "certainty"? Coexistence, change and some repercussions of native title in Northern Queensland', Anthropological Forum, 13 (1): 27-48.

Sullivan, P. 1996. All Free Man Now: Culture, Community and Politics in the Kimberley Region, North-Western Australia, Aboriginal Studies Press, Canberra.

Sullivan, P. 2001. Paper presented at the session 'Articulating culture: understanding engagements between Indigenous and non-Indigenous lifeworlds', Australian Anthropological Society Annual Conference, The Australian National University, 3 October.

Sullivan, P. 2005. 'Searching for the intercultural, searching for the culture', in M. Hinkson and B. R. Smith (eds), Figuring the Intercultural in Aboriginal Australia, Special Issue, Oceania, 75 (3): 183-94.

von Sturmer, J. R. 1984. 'The different domains', in Aborigines and Uranium, Australian Institute of Aboriginal Studies, Canberra. 
Wagner, R. 1967. The Curse of Souw: Principles of Daribi Clan Formation and Alliance, University of Chicago Press, Chicago.

Wagner, R. 1988. 'Visible sociality: the Daribi community', in J. F. Weiner (ed.), Mountain Papuans: Historical and Comparative Perspectives from New Guinea Fringe Highlands Societies, University of Michigan Press, Ann Arbor.

Weiner, J. F. 2003 'The Law of the Land: a review article', The Australian Journal of Anthropology, 14 (1): 97-110.

Weiner, J. F. n.d. 'Anthropology, law and the recognition space', unpublished MS. 